\title{
CHARACTERIZATION AND NITRIDATION BEHAVIORS OF SILICON SAWDUST GENERATED IN THE PHOTOVOLTAIC INDUSTRY
}

\author{
KARAKTERIZACIJA IN OBNAŠANJA NITRIRANEGA \\ SILICIJEVEGA PRAHU, NASTALEGA V FOTOVOLTAIČNI \\ INDUSTRIJI
}

\author{
Yu Lan', Yi Huang1, Bing Li', Xiaomin Li$^{1}$, Xiuqin Wei², Lang Zhou1, \\ Chuanqiang Yin ${ }^{1 *}$ \\ ${ }^{1}$ Institute of Photovoltaics, Nanchang University, 999 Xuefu Avenue, Honggutan New District, Nanchang City, \\ Jiangxi Province, 330031, China \\ ${ }^{2}$ School of Materials Science and Engineering, Nanchang University, 999 Xuefu Avenue, Honggutan New District, Nanchang City, \\ Jiangxi Province, 330031, China \\ Prejem rokopisa - received: 2019-12-22; sprejem za objavo - accepted for publication: 2020-06-09
}

doi:10.17222/mit.2019.304

\begin{abstract}
Characterization of the silicon-sawdust powders generated in the photovoltaic industry, and experiments of their nitridation were carried out. The results show that a layer of amorphous silicon is present on the particles of silicon sawdust. In addition, there is a lattice distortion in the crystal portion of the sawdust powders. An extra exothermic process accompanied by acceleration of nitridation occurs in the early stage of the nitridation of sawdust silicon, presumably because of the crystallization of the amorphous phase of silicon sawdust. A successful preparation of $>95 w / \% \alpha-\mathrm{Si}_{3} \mathrm{~N}_{4}$ powders taking place at $1300{ }^{\circ} \mathrm{C}$ for 3 hours was carried out.

Keywords: silicon sawdust, silicon nitride, nitridation, kinetics
\end{abstract}

Avtorji v članku opisujejo karakterizacijo silicijevega prahu, nastalega med rezanjem rezin z diamantno žago, za fotovoltaično industrijo in preizkuse nitriranja za njegovo ponovno uporabo. Rezultati analiz so pokazali, da je na površini prašnih delcev tanka plast amorfnega silicija. Poleg tega obstaja določen delež prašnih delcev z deformacijo kristalne rešetke. Avtorji so ugotovili, da med nitriranjem Si prahu nastopi zato poseben eksotermni proces, ki pospeši postopek nitriranja. Ta proces poteka v začetni (zgodnji) fazi nitriranja zaradi kristalizacije amorfne faze, ki se nahaja na površini Si prašnih delcev. Avtorji so uspešno reciklirali odpadni Si prah in pripravili $\alpha-\mathrm{Si}_{3} \mathrm{~N}_{4}$ prahove s čistostjo več kot 95 mas.\% z novim postopkom nitriranja s 3 urnim zadrževanjem Si prahu na $1300^{\circ} \mathrm{C}$ v čistem dušiku.

Ključne besede: silicijev prah, nastal med rezanjem rezin; fotovoltaika, silicijev nitrid, nitriranje, kinetika

\section{INTRODUCTION}

The global photovoltaic (PV) industry developed rapidly in the last decade, and more than $90 \%$ of its operations are based on silicon wafers. Up to now, all the silicon wafers have been produced with a wire saw. As the width of kerfs is about the same as the thickness of wafers, about $50 \%$ of the high-purity silicon becomes sawdust. Their recovery and utilization are undoubtedly very important to reduce the cost of PV power and release the environmental load they create. The reuse of recovered sawdust as the feedstock for the multi-crystalline silicon-ingot production used to attract a great deal of research effort. ${ }^{1,2}$ However, none of it led to an industrial practice due to the difficulty in meeting the demand for the solar-grade purity and the fact that the price of proper silicon feedstock has decreased drastically in the recent years.

*Corresponding author's e-mail:

cqyin@ncu.edu.cn (Chuanquiang Yin)
Other simple uses of sawdust, such as using it as the raw material for refractory ceramics, deoxidizer in steel making or alloying material for Al-Si alloy making are regretfully of a much lower value than sawdust ought to have. Although it is difficult to reach a purity of 6-7 N, i.e., the standard for solar cells, sawdust can be easily cleaned to a purity of 4-5 N, ${ }^{3}$ appropriate for highervalue utilization. In recent years, we have developed a patented route of producing high-purity $\alpha-\mathrm{Si}_{3} \mathrm{~N}_{4}$ powders using the nitridation of sawdust. Both $\alpha$ and $\beta$ phases of $\mathrm{Si}_{3} \mathrm{~N}_{4}$ are formed during the nitridation of silicon, and $\alpha-\mathrm{Si}_{3} \mathrm{~N}_{4}$ is preferable for applications in ceramics. The present paper shares some fundamental findings we obtained during this development, mostly related to the special structural feature of sawdust as compared to the conventional ball-milled silicon powders. Up to now, no similar study has been seen in commonly available published literature. 


\section{EXPERIMENTAL PART}

Silicon sawdust from a diamond-wire sawing workshop for monocrystalline-silicon-wafer production was used. Floatation separation, hydrochloric acid based on pickling and water rinsing were conducted to purify the sawdust. For comparison, a reference silicon powder ball-milled from fragments of broken silicon wafers were prepared. Ball-milled silicon powders are common raw materials used for the industrial production of $\mathrm{Si}_{3} \mathrm{~N}_{4}$ powders through direct nitridation.

The temperature profile of the nitridation process is illustrated in Figure 1. Different dwell temperatures were chosen for the experiment. Nitrogen of $99.999 \%$ purity was used as the reaction gas with 10 vol. $\% \mathrm{H}_{2} / 90$ vol.\% Ar of $99.999 \%$ purity as the diluent gas in the experimental system.

An X-ray diffractometer, the Bruker D8 FOCUS model, was used to characterize the structure and phase constitution of the silicon powders and nitridation products, using $\mathrm{Cu}-K_{\alpha 1}$ radiation with a step size of $0.02^{\circ}$ and

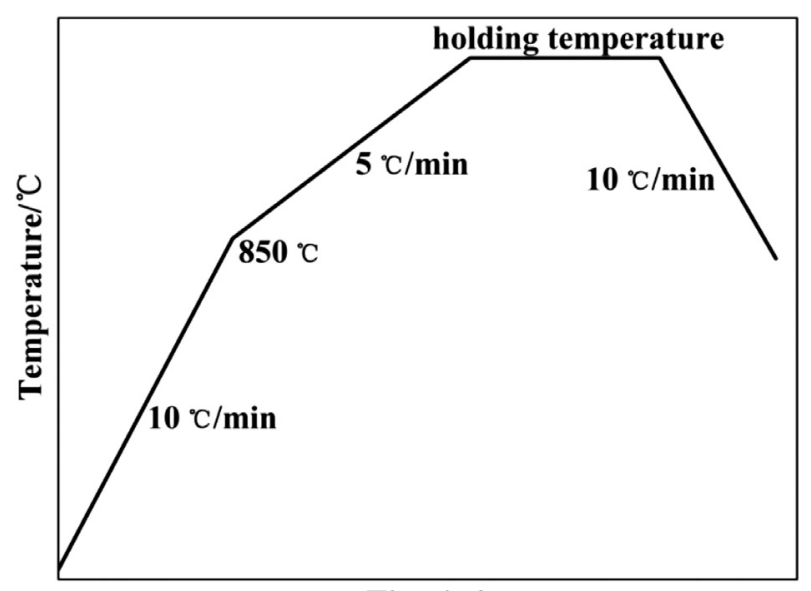

Time/min

Figure 1: Temperature profile of the nitridation process used for silicon-sawdust powders

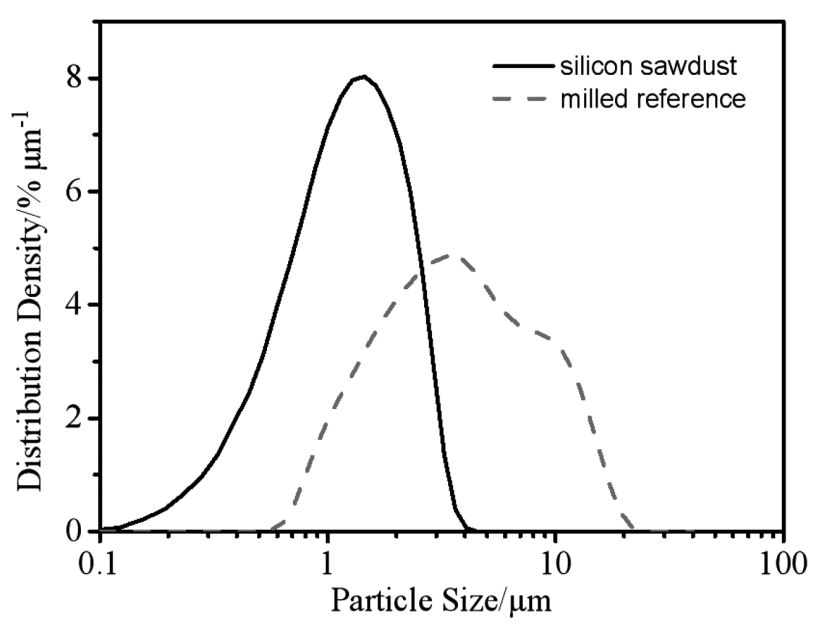

Figure 2: Obtained particle-size profiles of the purified sawdust and ball-milled reference silicon powder a scanning speed of $0.4 \mathrm{~s} / \mathrm{step}$. The quantitative-analysis method developed by Z. Jovanovic and S. Kimura ${ }^{4}$ was adopted to calculate the phase constitutions on the basis of the XRD results. A scanning electron microscope, the JSM $6701 \mathrm{~F}$ model, was used to examine the micromorphology of the silicon powders. A laser particle-size analyzer, the BT-9300H model, was used to determine the particle-size distribution of the silicon powders. Inductively coupled plasma atomic emission spectroscopy, the Optima 5300DV model, was used to analyze the metallic impurity of the purified silicon-sawdust powders. Combined differential scanning calorimetry (DSC) and thermal-gravity analysis (TGA) of the sawdust and the ball-milled reference silicon powders were conducted with a SDT-Q600 thermogravimetric analyzer.

\section{RESULTS AND DISCUSSION}

\subsection{Characterization of the silicon sawdust}

Concentrations of four major residual metals from the purified sawdust powders are listed in Table 1. As can be seen, the metallic impurity level corresponds well to the requirement related to commercial high-purity silicon nitride products.

Table 1: Concentrations of four major residual metals from the purified silicon sawdust, in mass fractions $(w / \%)$

\begin{tabular}{|c|c|c|c|}
\hline $\mathrm{Fe}$ & $\mathrm{Al}$ & $\mathrm{Cu}$ & $\mathrm{Ca}$ \\
\hline 0.00053 & 0.00033 & 0.00033 & 0.00094 \\
\hline
\end{tabular}

The obtained particle-size profile of the purified sawdust is plotted in Figure 2. The purified-silicon-sawdust particle size ranges from $\approx 0.1 \mu \mathrm{m}$ to $7 \mu \mathrm{m}$, with an average particle size of $1.15 \mu \mathrm{m}$. The ball-milled silicon powder is typically used in the industrial production of $\mathrm{Si}_{3} \mathrm{~N}_{4}$, and its average particle size is $4 \mu \mathrm{m}$.

Figure 3 shows the XRD patterns of the silicon sawdust powder and the reference silicon powder. Remarkable differences are revealed. Firstly, the diffraction peaks of the sawdust are greatly broadened, especially at the lower part of the peaks; Secondly, a broad peak appears in the spectrum of the sawdust at $\approx 52^{\circ}$ and it cannot be associated with crystalline silicon. As the particle sizes of the two types of silicon powders are in the order of microns, the first difference may not be attributed to the difference in the particle size. Besides, the shapes of the broadened peaks featured by a much greater broadening of their lower parts cannot be explained with the Scherrer broadening from the size effect. ${ }^{5}$

Previous studies of surface analyses of diamondwire-sawn silicon wafers with Raman spectroscopy showed that an amorphous layer of nanometer thickness is present on the surfaces. ${ }^{6,7}$ Molecular-dynamics simulations ${ }^{8,9}$ showed that a crystalline silicon surface cut by a diamond tip, as well as most parts of the silicon debris pushed away by the diamond tip transformed into amorphous-phase silicon. Therefore, we believe that a saw- 


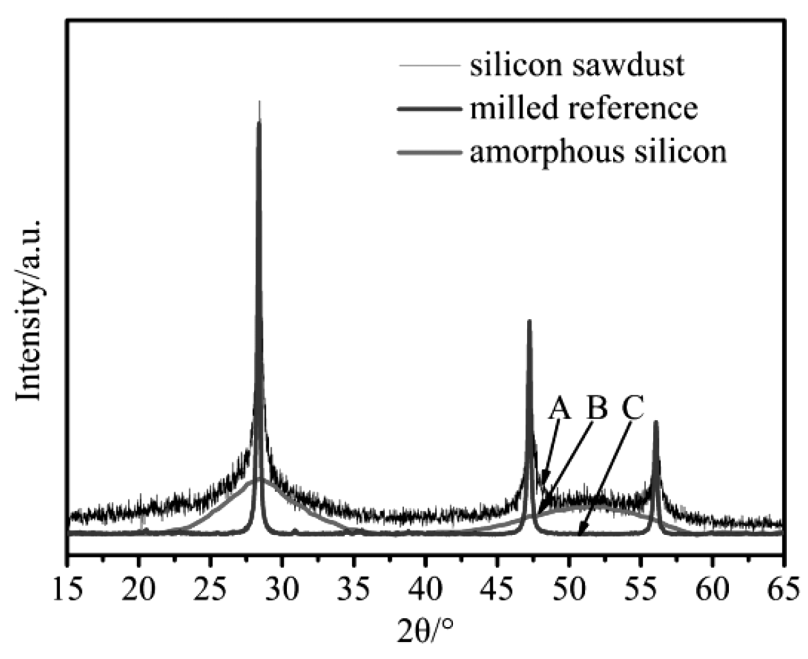

Figure 3: XRD patterns of the silicon sawdust: a), ball-milled crystalline silicon powder b) and amorphous silicon c), replotted from reference. $^{12}$ To make the graph clear, the spectrum for the sawdust was magnified eight times

dust particle actually consists of an amorphous surface layer and a crystalline silicon core, and it is the amorphous part that contributes to the observed bottom widening of the peaks and the extra hill in Figure 3a. Figure 3 also gives an XRD spectrum (C) of the amorphous silicon deposited on a Be substrate. The hills centered at $29^{\circ}$ and $52^{\circ}$ match well with the observed spectrum of the sawdust.

However, the significant widening of the higher parts of the peaks cannot be explained with the exiting of the amorphous phase in sawdust. We believe that underneath the amorphous layer, a severe crystal deformation must have happened, generating significant amounts of lattice defects and residual strains, which all contributed to the widening of the XRD peaks.

Diamond-wire sawing of silicon, which generates sawdust, is basically a plastic ploughing process. ${ }^{10,11} \mathrm{We}$ believe this mechanism is responsible for the severe deformation and the transition to the amorphous phase.

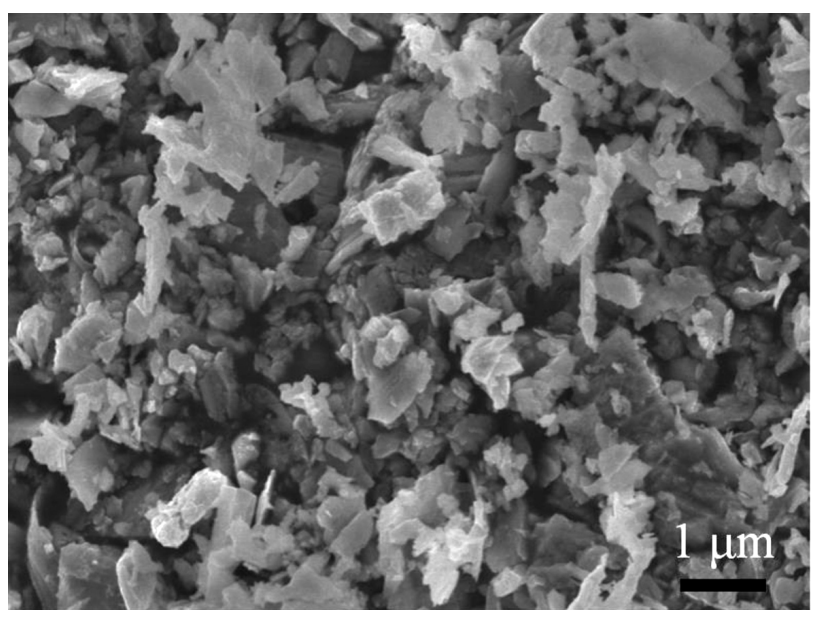

Figure 4: SEM micrograph of the purified silicon sawdust
During the ball milling of silicon, generating the reference silicon powders, simple brittle cracking of the silicon occurred, but it did not cause similar changes to the structure of silicon.

The micrograph of the silicon-sawdust powder is shown in Figure 4. The particles are mostly flaky, which agrees with the mechanism of diamond cutting. ${ }^{10}$ Compared with the usual granular shape, this kind of shape is believed to be of benefit to the reactivity.

\subsection{Nitridation behavior of the silicon sawdust}

First, nitridation experiments with pure $\mathrm{N}_{2}$ at a dwell temperature of $1380{ }^{\circ} \mathrm{C}$ indicated in Figure 1 were carried out. XRD patterns of the obtained products are given in Figure 5. As can be seen, the phase constitutions of the two products are greatly different. The product from the sawdust is mainly $\beta-\mathrm{Si}_{3} \mathrm{~N}_{4}$, with the rest being $\alpha-\mathrm{Si}_{3} \mathrm{~N}_{4}$, whereas the product from the reference milled silicon powder consists of residual silicon and $\alpha-\mathrm{Si}_{3} \mathrm{~N}_{4}$. Only a very small trace of $\beta-\mathrm{Si}_{3} \mathrm{~N}_{4}$ is detected. While the faster nitridation of silicon sawdust is not surprising, the large difference in the phase preference is unexpected and needs further attention to the reaction kinetics to understand the processes.

In order to understand the kinetics behaviors, combined DSC and TGA analyses of the isothermal reaction processes were conducted. Figures $\mathbf{6 a}$ and $\mathbf{6 b}$ present isothermal DSC and TGA curves of the two powders at $1380{ }^{\circ} \mathrm{C}$, and one more set of curves for the sawdust at $1300{ }^{\circ} \mathrm{C}$ in nitrogen. The samples were heated to the set temperature in $\mathrm{Ar}$ in less than an hour, then nitrogen was allowed to flow into the chamber and the counting of the reaction time started. The weight gain is a direct indication of the extent of nitridation, which incorporates the weight of nitrogen into the solid sample. A remarkable exothermic peak is present at an early stage of the saw-

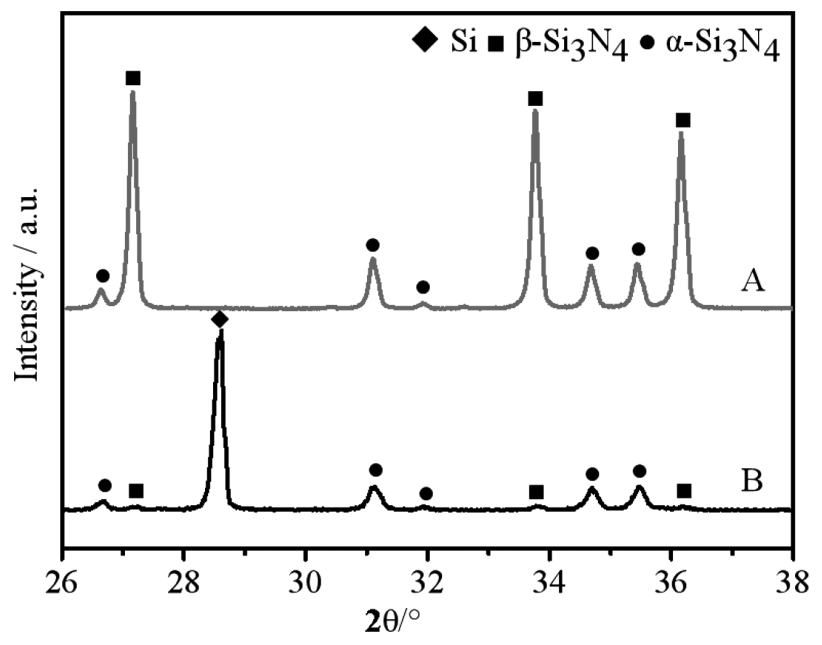

Figure 5: a) XRD patterns of the nitridation products obtained from silicon sawdust and b) ball-milled reference silicon powder. Refer to Figure 1 for the nitridation process, in which the dwell temperature is $1380{ }^{\circ} \mathrm{C}$ 

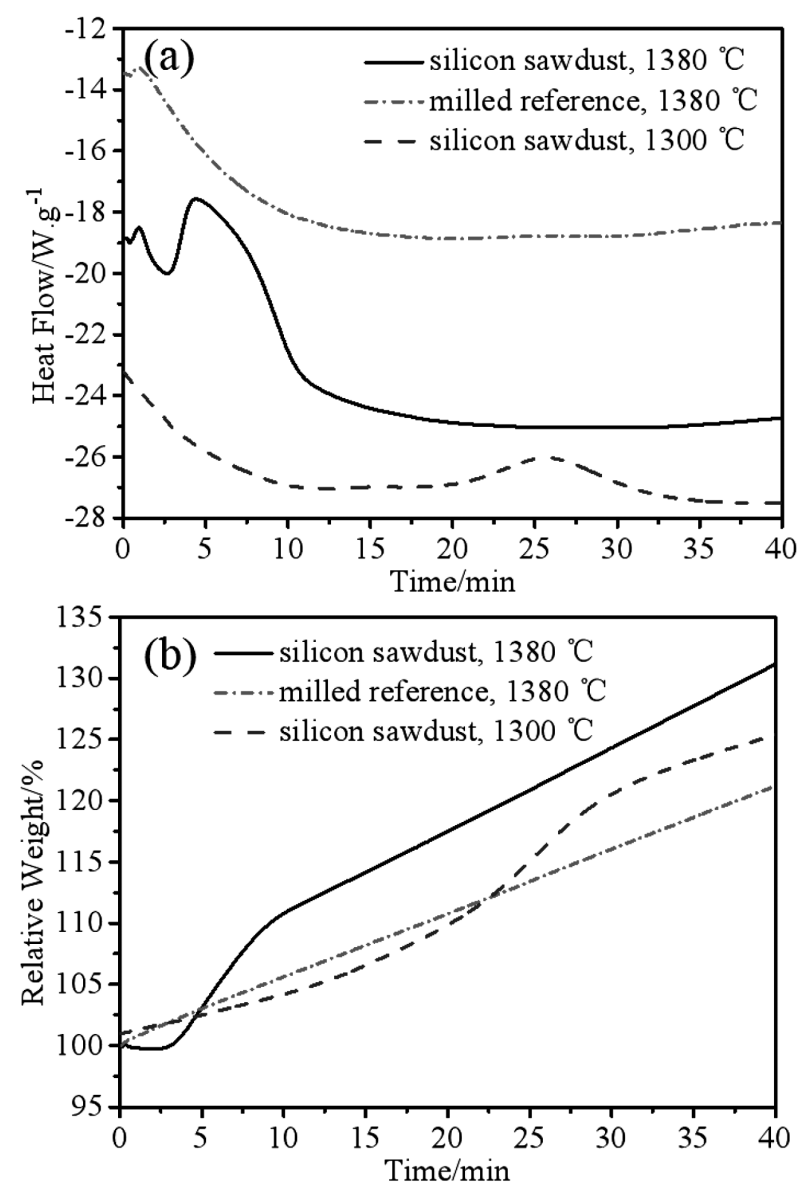

Figure 6: Isothermal behaviors of silicon sawdust and ball-milled reference silicon powder exposed to nitrogen: a) DSC, b) TGA

dust exposure to nitrogen, but no such peak is found for the milled reference silicon. Such a heat release may significantly raise the local temperature. Higher temperature is known to favor the formation of $\beta-\mathrm{Si}_{3} \mathrm{~N}_{4}$, while lower temperature favors the formation of $\alpha-\mathrm{Si}_{3} \mathrm{~N}_{4} \cdot{ }^{13}$ Once the $\beta$-phase nucleates during the above-mentioned heat-release stage, its subsequent growth keeps the same phase, though the subsequent temperature may not keep the excessive level, favoring the formation of the $\beta$-phase. Being associated with the exothermic heat, the acceleration of the nitridation of silicon sawdust is observed from Figure $6 \mathbf{b}$.

Nitridation of silicon is a strongly exothermic process. However, in a normal continuous nitridation process, no exothermic peak appears in the isothermal DSC curve. Only in the case of extra excessive heat that cannot be transferred away in time, such a peak would appear and the local temperature would rise up, leading to a rise in the nitridation rate, as can be seen in Figure $6 \mathbf{b}$. This is what happened to the reference powder and sawdust. In the nitridation experiments, much more powder is packed, more heat is generated and the transfer of heat from the interior of a sample pack is also more difficult so that the above difference is more pronounced. The fact that no residual silicon is detected in the product from the sawdust, while residual silicon in the product from the reference milled powder is still a major phase after the equivalent thermal process, as can be seen from Figure 5, also supports the above suggestion.

As to the reason(s) for the extra heat generation during the nitridation of silicon sawdust, further studies are required. Crystallization of a significant portion of the amorphous phase in the sawdust, as indicated by Figure 3, which is generally known to release heat, is a possible reason. In the DSC and TGA curves of the sawdust at a lower temperature $\left(1300{ }^{\circ} \mathrm{C}\right)$, the extra exothermic peak and the corresponding acceleration of nitridation are found to be delayed by $\approx 20 \mathrm{~min}$, with the DSC peak becoming smoother. This agrees with the above suggestion as due to a decrease in the temperature, the crystallization is delayed. ${ }^{14}$

The remarkably high reaction rate of the sawdust silicon is doubtlessly a significant advantage. However, for most applications of $\mathrm{Si}_{3} \mathrm{~N}_{4}$ powders in the manufacturing of structural ceramics, the $\alpha$-phase is preferred for its transformation to the $\beta$-phase during high-temperature sintering, enhancing the densifying process. ${ }^{15-17}$ So, a method to enhance the formation of the $\alpha$-phase instead of $\beta$-phase is required. Actually, at the industrial scale of the nitridation of ground silicon powders, a high proportion of the $\beta$-phase is also a problem due to the facts that the nitridation of silicon is always strongly exothermic and the size of packing in the production is inevitably large.

The control of the nitridation rate is crucial here. Current practices include dilution of the gas by adding an inert gas or dilution of the solid by mixing $\mathrm{Si}_{3} \mathrm{~N}_{4}$ powders with the silicon powders. ${ }^{18,19}$ Lowering the process temperature may also help, but it is unfortunately infeasible for the production involving ground silicon as the process may become unacceptably lengthy, as we can see

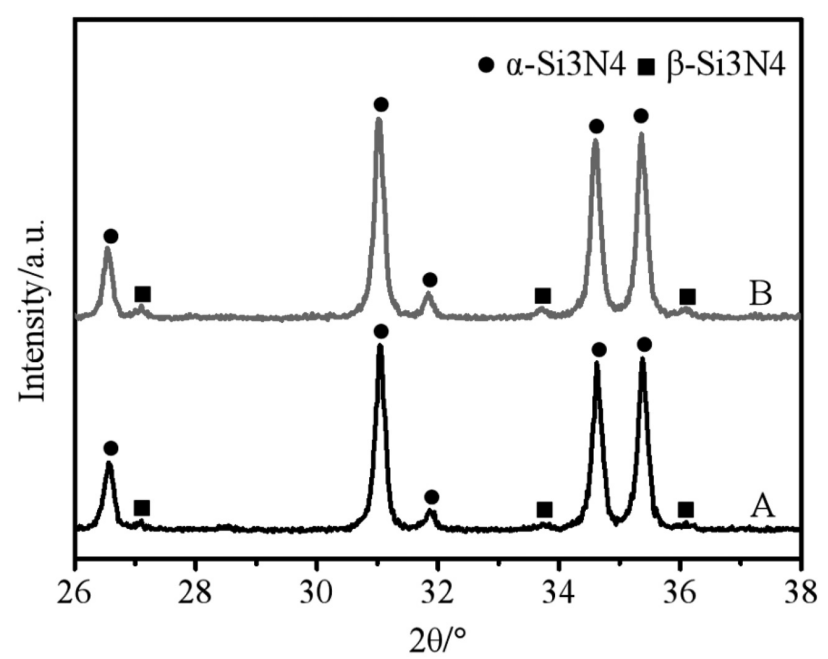

Figure 7: XRD patterns of the nitridation products obtained from silicon sawdust at different positions of the sample stack in the crucible: a) the top layer, b) the inner part. Refer to Figure $\mathbf{1}$ for the nitridation process, in which the dwell temperature is $1300{ }^{\circ} \mathrm{C}$ 
from the fact that in the current experiment, most of silicon remained unchanged after a three-hour exposure to $1380{ }^{\circ} \mathrm{C}$.

For the silicon sawdust with a remarkably high reaction rate, we chose to lower the process temperature to prevent an excessive temperature rise, which stimulates the formation of the $\beta$-phase. A nitridation experiment with the dwell temperature lowered to $1300{ }^{\circ} \mathrm{C}$ was carried out. The XRD patterns of the resultant products for the top layer and inner part of the packed sample powder are presented in Figure 7. As we can see, the $\alpha-\mathrm{Si}_{3} \mathrm{~N}_{4}$ phase becomes overwhelmingly dominant, though a small amount of residual silicon is also present. Table 2 lists the phase constitutions obtained on the basis of the XRD patterns. The amounts of the residual silicon and $\beta$ - $\mathrm{Si}_{3} \mathrm{~N}_{4}$ phase in both the top layer and inner part of the sample stack from the crucible are within, or just slightly over, the acceptable limits for most silicon nitride ceramic products. It is quite encouraging that with a significantly lower processing temperature, the time required is still much shorter than that of the nitridation of the ball-milled silicon used to reach the same low level of residual silicon.

Table 2: Phase constitutions of the nitridation products of the silicon sawdust at different positions of the sample stack in the crucible $(w / \%)$, as obtained from the XRD data in Figure 7

\begin{tabular}{|l|c|c|c|}
\hline & $\alpha-\mathrm{Si}_{3} \mathrm{~N}_{4}$ & $\beta-\mathrm{Si}_{3} \mathrm{~N}_{4}$ & $\mathrm{Si}$ \\
\hline The top layer & 97.9 & 1.1 & 1.0 \\
\hline The inner part & 95.0 & 3.9 & 1.1 \\
\hline
\end{tabular}

\section{CONCLUSIONS}

Based on the present studies, we conclude that:

A layer of amorphous silicon is present on the particles of the silicon sawdust generated during the silicon-wafer production with diamond wire sawing, resulting in a significant amount of amorphous silicon phase in the sawdust. In addition, there is a lattice distortion in the crystal portion of the sawdust powder.

Nitridation of purified silicon sawdust is generally much faster than for the conventional ball-milled silicon powder, even when the process temperature is significantly lower.

An extra exothermic process accompanied by an acceleration of nitridation occurs in an early stage of the nitridation of the sawdust silicon, presumably because of the crystallization of the amorphous phase of the silicon sawdust. It enhances the $\beta-\mathrm{Si}_{3} \mathrm{~N}_{4}$ phase formation at $1380{ }^{\circ} \mathrm{C}$.

A successful preparation of high-purity $\alpha-\mathrm{Si}_{3} \mathrm{~N}_{4}$ phase powders was achieved using the nitridation of silicon sawdust at a relatively low temperature, $1300^{\circ} \mathrm{C}$, in only $3 \mathrm{~h}$. The amount of the $\alpha$-phase obtained was higher than $95 w / \%$ and the amount of the residual silicon was reduced to $1 w / \%$.

\section{Acknowledgement}

This work was financially supported by the Youth Long-Term Project of the Jiangxi Province to Introduce Leading Innovative Talents, China (Grant No. jxsq2018106023), the Fundamental Research Fund for the Nanchang University, China (Grant No. cx2016017) and the Innovation and Entrepreneurship Training Program for College Students of the Nanchang University, China (Grant No. 20190402181).

\section{REFERENCES}

${ }^{1}$ D. Sarti, R. Einhaus, Silicon feedstock for the multi-crystalline photovoltaic industry, Solar Energy Materials and Solar Cells, 72 (2002), 1-4, 27-40, doi:10.1016/s0927-0248(01)00147-7

${ }^{2}$ D. G. Li, P. F. Xing, Y. X. Zhuang, F. Li, G. F. Tu, Recovery of high purity silicon from SoG crystalline silicon cutting slurry waste, Transactions of Nonferrous Metals Society of China, 24 (2014) 4, 1237-1241, doi:10.1016/S1003-6326(14)63184-8

${ }^{3}$ K. Tomono, S. Miyamoto, T. Ogawa, H. Furuya, Y. Okamura, Recycling of kerf loss silicon derived from diamond-wire saw cutting process by chemical approach, Separation and Purification Technology, 120 (2013), 304-309, doi:10.1016/j.seppur.2013.10.014

${ }^{4}$ Z. Jovanović, S. Kimura, Use of Two-Phase Standards of Unknown Compositions to Determine Calibration Constants for Powder XRD by Linear Regression, Journal of the American Ceramic Society, 77 (1994) 8, 2226-2228, doi:10.1111/j.1151-2916.1994.tb07127.x

${ }^{5}$ H. P. Klug, L. E. Alexander, X-ray diffraction procedures for polycrystalline and amorphous materials, John Wiley and Sons, Inc., New York, 1954, 716

${ }^{6}$ J. W. Yan, T. Asami, H. Harada, T. Kuriyagawa, Fundamental investigation of subsurface damage in single crystalline silicon caused by diamond machining, Precision Engineering, 33 (2009) 4, 378-386, doi:10.1016/j.precisioneng.2008.10.008

${ }^{7}$ A. K. R. C. Diamond wire-sawn silicon wafers from the lab to the cell production, Proc. of the $24^{\text {th }}$ European Photovoltaic Solar Energy Conference and Exhibition, Hamburg, Germany, 2009, 1400-1405

${ }^{8}$ Q. H. Tang, F. H. Chen, MD simulation of phase transformations due to nanoscale cutting on silicon monocrystals with diamond tip, Journal of Physics D: Applied Physics, 39 (2006) 16, 3674-3679, doi:10.1088/0022-3727/39/16/022

${ }^{9}$ W. C. D. Cheong, L. C. Zhang, Molecular dynamics simulation of phase transformations in silicon monocrystals due to nano-indentation, Nanotechnology, 11 (2000) 3, 173-180, doi:10.1088/0957$4484 / 11 / 3 / 307$

${ }^{10}$ E. Cai, B. Tang, W. Fahrner, L. Zhou, Characterization of the surfaces generated by diamond cutting of crystalline silicon, Proc. of the $26^{\text {th }}$ European Photovoltaic Solar Energy Conference and Exhibition, Hamburg, Germany, 2011, 1884-1886

${ }^{11}$ X. S. Han, B. Lin, S. Y. Yu, S. X. Wang, Investigation of tool geometry in nanometric cutting by molecular dynamics simulation, Journal of Materials Processing Technology, 129 (2002) 1-3, 2-5, doi:10.1016/S0924-0136(02)00585-X

${ }^{12}$ T. D. Hatchard, J. R. Dahn, In situ XRD and electrochemical study of the reaction of lithium with amorphous silicon, Journal of The Electrochemical Society, 151 (2004) 6, 838-842, doi:10.1149/1.1739217

${ }^{13}$ H. M. Jennings, On reactions between silicon and nitrogen, Journal of Materials Science, 18 (1983) 4, 951-967, doi:10.1007/ BF00551961

${ }^{14}$ R. B. Iverson, R. Reif, Recrystallization of amorphized polycrystalline silicon films on $\mathrm{SiO}_{2}$ : Temperature dependence of the crystallization parameters, Journal of Applied Physics, 62 (2011) 5, 1675-1681, doi:10.1063/1.339591 


\section{Y. LAN et al.: CHARACTERIZATION AND NITRIDATION BEHAVIORS OF SILICON SAWDUST ...}

${ }^{15}$ W. F. Dresslet, H. J. Kleebe, M. J. Hoffmann, M. Riihleb, G. Petzow, Model experiments concerning abnormal grain growth in silicon nitride, Journal of European Ceramics Society, 16 (1996) 1, 3-14, doi:10.1016/0955-2219(95)00175-1

${ }^{16}$ G. Ziegler, J. Heinrich, G. Wötting, Relationships between processing, microstructure and properties of dense and reaction-bonded silicon nitride, Journal of Materials Science, 22 (1987) 9, 3041-3086 doi:10.1007/BF01161167

${ }^{17}$ L. Ceja-Cárdenas, J. Lemus-Ruíz, D. Jaramillo-Vigueras, S. D. de la Torre, Spark plasma sintering of $\alpha-\mathrm{Si}_{3} \mathrm{~N}_{4}$ ceramics with $\mathrm{Al}_{2} \mathrm{O}_{3}$ and $\mathrm{Y}_{2} \mathrm{O}_{3}$ as additives and its morphology transformation, Journal of Alloys and Compounds, 501 (2010) 2, 345-351, doi:10.1016/j.jallcom. 2010.04.102
${ }^{18}$ M. Maalmi, A. Varma, W. C. Strieder, Reaction-bonded silicon nitride: experiments and model, Chemical Engineering Science, 53 (1998) 4, 679-689, doi:10.1016/S0009-2509(97)00344-8

${ }^{19}$ J. H. Yang, L. S. Han, Y. X. Chen, G. H. Liu, Z. M. Lin, J. T. Li, Effects of pelletization of reactants and diluents on the combustion synthesis of $\mathrm{Si}_{3} \mathrm{~N}_{4}$ powder, Journal of Alloys and Compounds, 511 (2012) 1, 81-84, doi:10.1016/j.jallcom.2011.08.057 